\title{
The association between cash flow variables and market risk on the Johannesburg Stock Exchange: an empirical analysis
}

\author{
Wessie J.A. Wessels, Johan du P. Smith, Wim R. Gevers* \\ University of Stellenbosch Business School, P.O. Box 610, Bellville 7535, Republic of South Africa
}

Received March 1993, accepted April 1993

\begin{abstract}
Cash flow from operations can be considered an important indicator of the quality of income of a company. The value of cash flow data was emphasized by Ismail \& Kim who found that cash-flow-based accounting betas have significant incremental explanatory power over earnings-based betas in explaining the variability in market risk. In this article similar research is reported which was conducted on a sample of companies extracted from the Industrial Section of the Johannesburg Stock Exchange and using the methodology proposed by Ismail \& Kim. A three year moving average smoothing procedure was also applied to the accounting return variables in order to reduce the effect of shortterm influences on the cash flow. Although it was not possible from the research to obtain similar statistically significant results for the South African market (partly because of the relatively small sample size), it was found that the simple linear regression model based on the smoothed cash flow beta did provide significant explanatory power of the variability in market beta.
\end{abstract}

Kontantvloei vanuit die bedryfsgedeelte van 'n maatskappy kan as 'n belangrike aanwyser dien van die kwaliteit van inkomste. Die waarde van kontantvloeidata is deur Ismail \& Kim beklemtoon toe hulle bepaal het dat kontantvloeigebaseerde rekeningkundige betas betekenisvolle inkrementele inligting teenoor verdienstebetas bevat in die beskrywing van die variabiliteit van die markrisiko. In hierdie artikel word soortgelyke navorsing gerapporteer wat op 'n steekproef van maatskappye uit die Industriële Afdeling van die Johannesburgse Effektebeurs uitgevoer is, deur van die metodologie soos deur Ismail \& Kim voorgestel is, gebruik te maak. ' $n$ Drie-jaar bewegende gemiddelde gladstrykingsproses is ook op die rekeningkundige veranderlikes toegepas om die effek van korttermyninvloede op die kontantvloei te minimaliseer. Alhoewel dit nie moontlik was om uit die navorsing soortgelyke statisties betekenisvolle resultate te verkry nie (moontlik deels as gevolg van die betreklik klein steekproefgrootte), is daar tog bepaal dat die enkelvoudige regressiemodel wat op die gladgestrykte kontantvloeibeta gebaseer is, betekenisvolle inligting aangaande die variabiliteit in die markbeta bevat.

*Author to whom correspondence should be addressed.

\section{Introduction}

During periods of high inflation a closer focus on corporate cash flow management may well be warranted. The effect of inflation on financial statements can be substantial, and rising costs, an increase in investment in working capital and the increasing cost of replacing fixed assets are all factors that place an increasing burden on cash flow. Cash flow information tends to be masked by accounting allocations in the financial statements. In South Africa, double digit inflation coupled to substantial swings in the business cycle emphasizes the need for cash flow information and management.

Ijiri (1980) and Drtina \& Largay (1985) found that it was difficult to determine actual cash flows from published data. Prior to the disclosure of cash flow data it could thus have been difficult for investors to accurately identify the relevant cash flow effects from published accounting data. In an attempt to determine the value of estimated cash flow data, Ismail \& Kim (1989) found that cash flow-based accounting betas contained significant incremental explanatory power over carnings-based betas in describing the variability of market risk.

In South Africa no research has as yet been published on the value of cash flow data as perceived by the market participants. The purpose of the research described in this article is thus to investigate whether similar conclusions to those found by Ismail \& Kim (1989) could be drawn in the South African context.

In the next section the related research is reviewed, while the research design is described in the third section. The results are reported next, followed by a number of concluding remarks.

\section{Review of related research}

Bhattacharya (1986: 130) compared the expansion of the cash flow concept to that of financial mobility, thus representing the dynamic role that funds can play towards the attainment of corporate objectives. Chastain \& Cianciolo (1986: 66) stated that cash is clearly superseding working capital as a measure of financial health. This view was confirmed by Kochanek \& Norgaard (1987: 27-31).

Beaver \& Manegold (1975: 231-284) conducted research to determine the association between market-determined and accounting-determined measures of systematic risk, concluding that a statistically significant association did exist between market and accounting betas. Bowman (1979: 617-629) developed a theoretical basis for the relationship between a firm's leverage and accounting beta, and systematic risk, and also concluded that systematic risk is not a function of earnings variability, growth, size or dividend policy. Although at variance with empirical tests (Beaver, Kettler \& Scholes, 1970), Bowman pointed out that such results might indicate that the variable being tested is a surrogate for another variable (such as an accounting beta). Baran, Lakonishok \& Ofer (1980: 22-35) and Beaver et al. (1970: 654-681) reached essentially similar conclusions. Dhaliwal (1986: 656) calculated accounting betas on a before tax and interest basis, and then adjusted for taxes and financial leverage. 
Ismail \& Kim (1989: 125-136) investigated whether cash flow-based measures of risk have an incremental ability to explain cross-sectional variation in market betas beyond that provided by earnings-based measures. The research was conducted primarily on the basis of a multiple regression model with market beta as the dependent variable, and accounting betas as the independent variables. This follows on earlier work in this regard by Beaver \& Manegold (1975), Bowman (1979), Baran, et al. (1980) and Beaver, et al. (1970). They concluded from this study that the addition of funds or cash flow-based risk measures significantly improved the explanatory power of regression models which use an accrual-based risk measure. They also found that the earnings beta does not possess incremental explanatory power beyond that provided by either funds or cash flow betas. This is at variance with the findings of Gombola \& Ketz (1983: 105-114), Bowen, Burgstahler \& Daley (1986: 713-725) and Wilson (1986: 165-203).

In South Africa, Retief, Hamman \& Affleck-Graves (1984) investigated the relationship between accounting determined betas and market risk. No specific cash flow issues were addressed, and the study concluded that pure accounting betas did not appear to be the sole determinants of risk in the South African context.

\section{Research design}

\section{Sampling procedure}

For the purpose of this study, the population was defined as listed companies in the Industrial Section of the JSE, with complete and uninterrupted financial data available on the data base of the University of Stellenbosch Business School, with no change to financial year-ends during this period. In order to calculate accounting betas, a fairly long time series of accounting data is required for each company selected for this study. In addition, it is required that all the companies selected have the same financial year-end. Since June is the most popular year-end for industrial companies, the sample is limited to June year-end companies.

The optimal period for investigation was found to stretch from 1973 to 1987, yielding a total of 53 companies. By extending the period for a further year, five companies were lost, and a further seven companies were lost if the period were to be extended to 1989. Data availability did not allow for periods prior to 1973. No advantage in terms of data points could be obtained by staring a year or two later and extending the period into the 1990s. The list of companies selected is shown as Appendix A.

In order to extend the number of data points per company, it was decided to also include 1988 in the data set. Of the five companies that were no longer listed as June year-end companies, two (namely Montays Ltd. and Welfit Oddy Holdings Ltd.) only have continuous accounting data available up to 1987. This is inconsistent with the definition of the sample, which requires continuous accounting data through to 1988. Although initially retained in the sample, this inconsistency solved itself, as no significant cash flow betas could be obtained for these companies. Another inconsistency is a year-end change in 1988 for the companies Abercom Group Ltd. (to August 1988), National Bolts Ltd. (to December 1988) and Central African Cables Ltd. (to December 1988). The income statement data for 1988 was linearly adjusted to address this, to obtain representative 12 month numbers.

\section{Research methodology}

The research approach adopted closely follows that of Ismail \& Kim (1989) and is structured on the basis of single and multiple regression analysis models, with market beta as the dependent variable and the various accounting betas (as calculated) as the independent variables. The thrust of the research is firstly to test the explanatory power of the cash flow-based betas in terms of the variability of the market beta (and thus market risk), and secondly to determine the incremental explanatory power in this regard of the eamings, funds flow and cash flow risk measures relative to each other.

The market beta is determined from the application of the familiar market model, whilst accounting return variables for the calculation of the accounting betas are calculated from the data base in terms of the following definitions:

Earnings: Income available to common equity.

Funds flow 1: Income available to common equity plus depreciation.

Funds flow 2: Income available to common equity plus depreciation and deferred taxes.

Cash flow: Cash flows generated from continuing operations, with cash flows defined as income available to common equity plus depreciation, deferred taxes and the change in non-cash working capital.

In order to take the orders of magnitude of the accounting numbers for the different companies in the sample into account, they should be deflated by some quantity of the same magnitude. Dhaliwal (1986) used total assets of the firm as the deflator of the accounting variables. Christie (1987: 233) concluded from research on cross-sectional analysis in accounting research that the correct deflator for returns studies is the market value of ordinary share capital at the beginning of the period, as the use of any other deflator generated a correlated omitted variable problem. For this reason all the accounting variables as defined above were deflated by dividing them by the beginning of the period market value of common equity.

The accounting betas which are to be used in the regression models are estimated using a time series regression process. The effect of non-stationarity of the beta coefficients is addressed in this research by the application of Vasicek's (1973) Bayesian adjustment technique to the initial estimates of both market beta and accounting betas, at the individual company level.

\section{Market beta}

Bradfield (1989) has confirmed the validity of the CAPM or market model for the JSE through empirical testing. The market model can be stated as follows:

$R_{i, t}=\alpha_{i}+\beta_{i} R_{m, t}+\varepsilon_{i, t}$ 
where:

$R_{i, t}=$ return on security $i$ in period $t ;$

$\alpha_{i}=$ intercept;

$\beta_{i}=$ market beta for security $i$

$\mathbf{R}_{\mathrm{m},}=$ return on the market portfolio; and

$\varepsilon_{i, l}=$ residual retum on security $i$ in period $t$.

The market beta was estimated for the sample companies using this model, using monthly observations during the period 1973 to 1988. The JSE Actuaries Industrial Index and its associated dividend yield was used as a market proxy. In determining the price relative return on a security, capital structure changes were taken into account using the equivalent dividends method as described by De Villiers (1988) and extended by Gevers (1989).

Market betas for the companies Press Supplies Holdings Ltd., Towles, Edgar Jacobs Ltd. and The Union Cold Storage of South Africa Ltd. as calculated, were not significantly different from zero at the 5\% level and were thus removed from the sample, reducing the sample size by 3 to 50.

\section{Accounting return variables}

The four return variables (as defined above) were termed EARN, FFLOW1, FFLOW2 and CHFLOW respectively, and calculated as follows:

$$
\begin{aligned}
\text { EARN }= & A_{t} \div B_{t-1} \\
\text { FFLOW1 }= & A 1_{t} \div B_{t-1} \\
\text { FFLOW2 }= & A 2_{t} \div B_{t-1} \\
\text { CHFLOW }= & {\left[A 2_{t}-(\text { Current assets }- \text { Current li- }\right.} \\
& \text { abilities }-A 3)_{t}+(\text { Current assets }- \\
& \text { Current liabilities } \left.-A 3)_{t-1}\right] \div B_{t-1}
\end{aligned}
$$

where:

$$
\begin{aligned}
\mathrm{A}= & \text { (Profit after taxation) }+ \text { (Earnings from associated } \\
& \text { companies) }- \text { (Minority share in profit) } \\
\mathrm{A} 1= & \mathrm{A}+(\text { Current depreciation })+(\text { Additional depre- } \\
& \text { ciation) } \\
\mathrm{A} 2= & \mathrm{A} 1+(\text { Deferred taxation }) \\
\mathrm{A} 3= & \text { (Loans) }+ \text { (Deposits) }+(\text { Cash) }- \text { (Bank overdraft) } \\
& - \text { (Short term loans) }- \text { (Dividends payable) } \\
\mathrm{B}= & \text { (Number of issued ordinary shares) } \mathrm{x} \text { (Share price) } \\
\mathrm{t}= & \text { time period (years from } 1973 \text { to 1988) }
\end{aligned}
$$

(The share prices used were the closing prices on the last day that the share traded, closest to the end of June, for 1973 to 1988.)

This method of calculating cash flow variables corresponds with the indirect method for calculating cash flow as described by Drina \& Largay (1985: 315).

\section{Accounting betas}

The accounting return variables were used to estimate accounting betas, using the following time series regression:

$r_{i, t}=a_{i}+b_{i} r_{m, t}+e_{i, l}$

where:

$r_{i, l}=$ accounting return for commany $i$ in period $t$;

$\mathrm{a}_{\mathrm{i}}=$ intercept for company $\mathrm{i}$;

$b_{i}=$ accounting beta for company $i$; $\mathbf{r}_{\mathrm{m}, t}=$ market index for accounting retums, computed as the simple average of the sample accounting returns $\mathbf{r}_{\mathrm{i}, \mathrm{i}}$ in period $\mathrm{t}$;

$e_{i,}=$ residual return on company $i$ in period $t$.

With the calculation of $r_{m, s}$ as a market index proxy, it was noted that large variations occurred between calculated company values in a given time period. This significantly affected the average, which was further exacerbated by the relatively small sample size. In the light of this, it was decided to use the median accounting retum, rather than the simple average as used by Ismail \& $\mathrm{Kim}$ (1989).

In an effort to smooth the effect of short term variations in the accounting variables that could influence and mask actual cash flow (such as short term investment), further return variables were calculated as the three year moving average of the defined variables. Although effectively condensing the time period, this does provide the required smoothing effect. Accounting variables determined thus were identified as EARNM3, FFLOW1M3, FFLOW2M3 and CHFLOWM 3 respectively, and accounting betas calculated from these variables were termed BEM3, BFF1M3, BFF2M3 and BCHFM3. Where these accounting betas were not significant at the $5 \%$ level, the original (unsmoothed) accounting betas were included in the data vector. Although this approach may be criticized on the grounds that not all betas in the data vector have a similar base, this is offset by the increase in the number of data points (and thus of information) and the improvement of the data vector. For the calculation of the smoothed accounting betas, the market index, $r_{m, l}$, was represented by the unsmoothed median values of the relevant accounting variables.

The following accounting retum variables are used in the calculation of accounting betas as shown:

$\begin{array}{ll}\text { Accounting return variable } & \text { Accounting beta } \\ \text { EARN } & \text { BE } \\ \text { EARNM3 } & \text { BEM3 } \\ \text { FFLOW1 } & \text { BFF1 } \\ \text { FFLOW1M3 } & \text { BFF1M3 } \\ \text { FFLOW2 } & \text { BFF2 } \\ \text { FFLOW2M3 } & \text { BFF2M3 } \\ \text { CHFLOW } & \text { BCHF } \\ \text { CHFLOWM3 } & \text { BCHFM3 }\end{array}$

Market beta is indicated as variable MB. Resultant accounting betas as well as the calculated market betas are available upon request from the authors.

\section{Relationship investigated}

The relationship between the market beta and the accounting betas was evaluated using the following multiple regression equation:

$M B_{i}=\beta_{0}+\beta_{1} X 1_{i}+\beta_{2} X 2_{i}+\varepsilon_{i}$

where:

$\mathrm{MB}_{\mathrm{i}}$ = market beta for company $\mathrm{i}$;

$\mathrm{X}_{\mathrm{i}}, \mathrm{X2}_{\mathrm{i}}=$ accounting betas for company $\mathrm{i}$, for the relevant model denoted in Table 5;

$\beta_{1} \quad=$ regression coefficients, $\mathrm{i}=0,1$ and 2 ; 
$\varepsilon_{\mathrm{i}} \quad=$ error term, which is assumed to be normally distributed with a mean of zero and a constant variance.

If the model estimated by Equation 7 is significant, it implies that the accounting betas are useful in describing the variability of the market betas. If either $\beta_{1}$ or $\beta_{2}$ is significantly different from zero, it implies that its associated accounting beta has incremental explanatory power. This model would be applicable to regression models 5 to $9 \mathrm{~A}$, as defined in Table 5. For regression models 1 to $4 \mathrm{~A}$ (single regression) the equation reduces to the following:

$\mathrm{MB}_{\mathrm{i}}=\beta_{0}+\beta_{1} \mathrm{X} 1_{1}+\varepsilon_{\mathrm{i}}$

where all variables are as defined before.

Initial analysis yielded disappointing results. It was observed that accounting beta values for the company Putco Ltd. (although statistically significant) were orders of magnitude higher than the corresponding values for other companies. Investigation revealed that this company consistently had very high depreciation expenses (relative to earnings) for the sample period. Being a transport company, a high proportion of the assets were subject to depreciation, and the bus fleet operated by the company was fully depreciated monthly over a ten-year period, with $51 \%$ of the value depreciated over the initial four years. This profoundly affected the accounting variables and thus the accounting betas, when compared to other companies in the sample. In order to avoid the effect of this anomaly, it was decided to remove this company from the sample, in order to obtain more meaningful results. The sample size was thus reduced to 49 companies.

The effect of non-stationarity of the beta coefficients have led to beta estimation errors in earlier studies. In order to overcome this problem, Vasicek's (1973) Bayesian adjustment technique was applied to the initial estimates of both market beta and accounting betas at the individual company level. Vasicek (1973) suggested that in the absence of other prior information, an appropriate choice of the prior density function of beta may be the cross-sectional distribution of the beta population from which the sample is drawn - in this case clearly the stocks traded on the JSE in the Industrial Section. As the parameters as stated are not known for the JSE, the Bayesian adjustment procedure was based on parameters assumed to be $b^{\prime}$ equal to 1 and $s^{\prime}{ }_{b}$ equal to 0.5 respectively. Vasicek (1973: 1237) observed that these values were appropriate parameter assumptions for the New York Stock Exchange.

The following formulae (Vasicek, 1973: 1236) were used in the calculation:

$$
b^{\prime \prime}=\frac{\left[\frac{b^{\prime}}{s_{b}^{\prime}{ }^{2}}+\frac{b}{s_{b}^{2}}\right]}{\left[\frac{1}{s_{b}^{\prime}{ }^{2}}+\frac{1}{s_{b}^{2}}\right]}
$$

$$
s_{b}^{\prime \prime}{ }^{2}=\frac{1}{\frac{1}{s_{b}^{\prime}{ }^{2}}+\frac{1}{s_{b}{ }^{2}}}
$$

where:

$\mathrm{b}^{n}=$ mean of the posterior distribution of beta;

$s^{\prime \prime}{ }_{b}^{2}=$ variance of beta;

$\mathbf{b}^{\prime}=$ best prior estimate of $\mathbf{b}^{\prime \prime}$;

$s_{b}^{\prime}=$ best prior estimate of $s^{n}{ }_{b}$; and

$s_{b}=$ standard error of the estimate $b$.

(The posterior distribution of beta can be assumed to be approximately normal, with mean $b^{\prime \prime}$ and variance $s^{n} b^{2}$, for regression sample point numbers greater than 20 . Here, with 49 companies in the sample, this condition is clearly fulfilled.)

The regression models for both the single and multiple regressions are defined in Table 1 . In all models the market beta $(\mathrm{MB})$ is considered as the dependent variable.

\section{Results}

The summary statistics of the betas are presented in Tables 2 and 3 for the unadjusted and adjusted betas respectively. From these results it is clear that cross-sectional standard deviations of the accounting betas are markedly higher than those of the market beta and also when compared with the findings of Baran et al. (1980), Beaver \& Manegold (1975) and Ismail \& Kim (1989). This could partly be due to the relatively small number of observations used to determine the estimates. The Bayesian adjustment procedure led to a marked reduction in the variability of the betas as well as a

\begin{tabular}{|c|c|c|}
\hline \multirow[b]{2}{*}{ Model number } & \multicolumn{2}{|c|}{ Independent variables } \\
\hline & $\mathbf{X} 1$ & $\mathbf{X} 2$ \\
\hline 1 & $\mathrm{BE}$ & - \\
\hline $1 \mathrm{~A}$ & BEM3 & - \\
\hline 2 & $\mathrm{BFF} 1$ & - \\
\hline $2 A$ & BFF1M3 & - \\
\hline 3 & BFF2 & - \\
\hline $3 A$ & $\mathrm{BFF} 2 \mathrm{M} 3$ & - \\
\hline 4 & $\mathrm{BCHF}$ & - \\
\hline $4 A$ & BCHFM3 & - \\
\hline 5 & $\mathrm{BE}$ & BFF1 \\
\hline $5 A$ & BEM3 & BFF1M3 \\
\hline 6 & BE & BFF2 \\
\hline $6 A$ & BEM3 & BFF2M3 \\
\hline 7 & $\mathrm{BE}$ & BCHF \\
\hline $7 \mathbf{A}$ & BEM3 & BCHFM3 \\
\hline 8 & BFF1 & BCHF \\
\hline $8 A$ & BFF1M3 & BCHFM3 \\
\hline 9 & BFF2 & BCHF \\
\hline $9 A$ & $\mathrm{BFF} 2 \mathrm{M} 3$ & BCHFM3 \\
\hline
\end{tabular}
convergence in the average and median values calculated.

Table 1 Regression models 
Table 2 Summary statistics of market and accounting betas: unadjusted betas

\begin{tabular}{llcccc}
\hline Description & Symbol & $\begin{array}{c}\text { Number of } \\
\text { Observations }\end{array}$ & Average & Median & $\begin{array}{c}\text { Standard } \\
\text { deviation }\end{array}$ \\
\hline Market beta & MB & 49 & 0.821 & 0.762 & 0.346 \\
Eamings beta & BE & 34 & 1.300 & 1.198 & 0.746 \\
(3 yr. moving ave) & BEM3 & 37 & 1.177 & 1.056 & 0.699 \\
Funds flow 1 beta & BFF1 & 33 & 1.439 & 1.186 & 1.109 \\
(3 yr. moving ave) & BFF1M3 & 34 & 1.249 & 1.080 & 1.040 \\
Funds flow 2 beta & BFF2 & 33 & 1.414 & 1.162 & 1.015 \\
(3 yr. moving ave) & BFF2M3 & 35 & 1.210 & 1.054 & 0.950 \\
Cash flow beta & BCHF & 20 & 2.054 & 1.600 & 1.260 \\
(3 yr. moving ave) & BCHFM3 & 22 & 1.627 & 1.130 & 1.069 \\
\hline $\mathrm{N}=49$ companies & & & & & \\
Period = 1973-1988 & & & & & \\
All betas significant at the 0.05 level & & & & & \\
\hline
\end{tabular}

Table 3 Summary statistics of market and accounting betas: Bayesian adjusted betas

\begin{tabular}{llcccc}
\hline Description & Symbol & $\begin{array}{c}\text { Number of } \\
\text { observations }\end{array}$ & Average & Median & $\begin{array}{c}\text { Standard } \\
\text { deviation }\end{array}$ \\
\hline Market beta & MB & 49 & 0.810 & 0.770 & 0.271 \\
Eamings beta & BE & 34 & 1.150 & 1.161 & 0.461 \\
(3 yr. moving ave) & BEM3 & 37 & 1.100 & 1.049 & 0.511 \\
Funds flow 1 beta & BFF1 & 33 & 1.199 & 1.144 & 0.460 \\
(3 yr. moving ave) & BFF1M3 & 34 & 1.088 & 1.065 & 0.489 \\
Funds flow 2 beta & BFF2 & 33 & 1.205 & 1.144 & 0.481 \\
(3 yr. moving ave) & BFF2M3 & 35 & 1.079 & 1.049 & 0.505 \\
Cash flow beta & BCHF & 20 & 1.350 & 1.336 & 0.373 \\
(3 yr. moving ave) & BCHFM3 & 22 & 1.172 & 1.101 & 0.399 \\
\hline $\mathrm{N}=49$ companies & & & & & \\
Period $=1973-1988$ & & & & \\
All betas significant at the 0.05 level & & & & \\
\hline
\end{tabular}

The product moment correlation matrices for the unadjusted and adjusted betas are given in Tables 4 and 5 . It can be seen that the adjustments made to derive the various measures of cash flow have an effect on the degree of correlation between the accounting betas - as adjustment proceeds to develop funds flow and cash flow, the correlation with the earnings beta decreases. The smoothed cash flow beta BCHFM3 has the highest correlation with the market beta, namely 0.383 (significant at the 10\% level). These results are consistent with the results reported by Ismail \& Kim (1989: 131), albeit at much lower levels of significance (see Tables 4 and 5).

The Bayesian adjustment process positively influenced the correlations, although significance levels were reduced in some cases. For BCHFM3, the correlation with market beta improved to 0.392 (significant at the 0.10 level).

The correlation matrices show a high degree of collinearity between the accounting betas. This indicates a substantial amount of common explanatory power in the accounting betas. Christie, Kennelly, King \& Schaefer (1984: 205) have noted that, in the presence of collinearity, the precision of estimation declines, and that significance levels thus tend to be understated.

The results of the regression analyses for the models shown in Equations 7 and 8 are given in Table 6 for the unadjusted betas and in Table 7 for the adjusted betas. For the simple linear models, Model 4A (smoothed cash flow beta BCHFM3) produced the best results, with a $R^{2}$-value of $14.7 \%$, at a significance level of $7.8 \%$. The Bayesian adjustment procedure generally has a moderately positive influence on the cash flow models. Results for model $4 \mathrm{~A}$ improved to a $\mathrm{R}^{2}$-value of $15.4 \%$ (at a significance level of $7.1 \%)$.

None of the multiple regression models were significant, in sharp contrast to the findings of Ismail \& Kim (1989: 133). Models $8 \mathrm{~A}$ and $9 \mathrm{~A}$ for both the unadjusted and adjusted betas have the lowest p-values. In both instances the cash 
Table 4 Product moment correlation matrix of market and accounting betas: unadjusted betas

\begin{tabular}{llllllllc}
\hline (Market beta = MB) & MB & BE & BEM3 & BFF1 & BFFIM3 & BFF2 & BFF2M3 \\
\hline Eamings beta & BE & 0.258 & - & - & - & - & - & - \\
(3 yr. moving ave) & BEM3 & $0.267^{*}$ & - & - & - & - & - & - \\
Funds flow 1 bela & BFF1 & $0.301^{*}$ & $0.898^{* * *}$ & $0.911^{* * *}$ & - & - & - & - \\
(3 yr. moving ave) & BFF1M3 & $0.280^{*}$ & $0.873^{* * *}$ & $0.905^{* * *}$ & - & - & - & - \\
Funds flow 2 bet & BFF2 & $0.318^{*}$ & $0.895^{* * *}$ & $0.909^{* * *}$ & $0.991^{* * *}$ & $0.975^{* * *}$ & - & - \\
(3 yr. moving ave) & BFF2M33 & $0.277^{*}$ & $0.877^{* * *}$ & $0.907^{* * *}$ & $0.982^{* * *}$ & $0.994^{* * *}$ & - & - \\
Cash flow beta & BCHF & 0.234 & $0.427^{*}$ & $0.453^{* *}$ & $0.400^{*}$ & $0.391^{*}$ & $0.411^{*}$ & $0.403^{*}$ \\
(3 yr. moving ave) & BCHFM3 & $0.383^{*}$ & $0.525^{* *}$ & $0.512^{* *}$ & $0.451^{* *}$ & 0.334 & $0.444^{* *}$ & 0.347 \\
\hline
\end{tabular}

* Significant at the 0.10 level

* Significant at the 0.05 level

*** Significant at the 0.01 level

Table 5 Product moment correlation matrix of market and accounting betas: Bayesian adjusted betas

\begin{tabular}{lllllllll}
\hline (Market beta = MB) & & MB & BE & BEM3 & BFF1 & BFF1M3 & BFF2 & BFF2M3 \\
\hline Eamings beta & BE & 0.211 & - & - & - & - & - & - \\
(3 yr. moving ave) & BEM3 & 0.236 & - & - & - & - & - & - \\
Funds flow 1 beta & BFF1 & 0.281 & $0.872^{* * *}$ & $0.842^{* * *}$ & - & - & - & - \\
(3 yr. moving ave) & BFF1M3 & 0.231 & $0.823^{* * *}$ & $0.899^{* * *}$ & - & - & - & - \\
Funds flow 2 beta & BFF2 & 0.269 & $0.825^{* * *}$ & $0.802^{* * *}$ & $0.975^{* * *}$ & $0.898^{* * *}$ & - & - \\
(3 yr. moving ave) & BFF2M3 & 0.210 & $0.792^{* * *}$ & $0.872^{* * *}$ & $0.911^{* * *}$ & $0.983^{* * *}$ & - & - \\
Cash flow beta & BCHF & 0.351 & $0.635^{* * *}$ & $0.648^{* * *}$ & $0.609^{* * *}$ & $0.572^{* * *}$ & $0.582^{* * *}$ & $0.566^{* * *}$ \\
(3 yr. moving ave) & BCHFM3 & $0.392^{*}$ & $0.531^{* *}$ & $0.556^{* * *}$ & $0.509^{* *}$ & $0.430^{* *}$ & $0.481^{* *}$ & $0.433^{* *}$ \\
\hline$\quad$ Significant at the 0.10 level & & & & & & \\
** Significant at the 0.05 level \\
*** Significant at the 0.01 level
\end{tabular}

flow beta variable, BCHFM3, has a coefficient that is significant at the $10 \%$ level, indicating slight evidence of incremental information. The collinearity of the fund flow and cash flow variables could have led to the understatement of the significance level. When this evidence is read in conjunction with the significance (at the $10 \%$ level) of model $4 \mathrm{~A}$, it is clear that the cash flow variable contains some information in describing the market risk. The evidence is, however, so slight, that the addition of the fund flow variables in the multiple regression model makes the whole model non-significant. It is thus not possible to attempt generalized conclusions about the incremental explanatory power of the accounting variables.

\section{Conclusion}

In this article the relationship between accounting betas, based on fund flow and cash flow concepts, and the market beta was investigated. A major issue of concem in this research was the relatively small size of the available sample. This contributed to the non-significance of the multiple regression models, as the relatively small data vectors are more severely affected by variability of the data components. This is one of the major differences with USA-based research, where substantially larger samples and data sets are available.

The results obtained from the analysis showed that a significant portion of the variability in market risk could be explained by the variability in the smoothed cash flow-based accounting betas. Due to the non-significance of the multiple regression models, it was not possible to draw a firm conclusion with regard to the incremental explanatory power of the cash flow-based betas over earnings-based betas. As such, this contrasts with the findings of Ismail \& $\mathrm{Kim}$ (1989) for the USA market.

The Bayesian adjustment procedure, as developed by Vasicek (1973), has proved valuable in the improvement of the results. The correlation analysis and the simple linear regression models show that the smoothed cash flow beta (BCHFM3) does possess statistically significant explanatory power as regards the variability in market risk, as represented by the market beta. The results for the simple linear regression model $4 A$ achieved a $R^{2}$-value of $15.4 \%$, which can be interpreted that $15.4 \%$ of the variability in market risk can be explained by the smoothed cash flow beta.

It does seem as if the cash flow information indeed explains a significant portion of market risk in the South 
Table 6 Regressions of market beta on accounting betas: unadjusted betas

\begin{tabular}{|c|c|c|c|c|c|c|c|}
\hline \multirow{2}{*}{\multicolumn{3}{|c|}{ Independent variables }} & \multicolumn{2}{|c|}{ Coefficients (t-statistics; P-value) } & \multirow[b]{2}{*}{$\mathbf{R}^{2}$} & \multirow{2}{*}{$\begin{array}{l}\text { Model } \\
\text { F.value }\end{array}$} & \multirow{2}{*}{$\begin{array}{l}\text { Model } \\
\text { P-value }\end{array}$} \\
\hline Model & & & $\mathbf{x} 1$ & $\mathbf{X} 2$ & & & \\
\hline 1 & $\mathrm{BE}$ & - & $0.135(1.510 ; 14 \%)$ & - & 0.067 & 2.280 & $14.0 \%$ \\
\hline 1A & BEM3 & - & $0.144(1.642 ; 11.1 \%)$ & - & 0.072 & 2.700 & $11.1 \%$ \\
\hline 2 & BFF1 & - & $0.106(1.759 ; 8.6 \%)$ & 一 & 0.091 & 3.090 & $8.6 \%$ \\
\hline $2 \mathrm{~A}$ & BFF1M3 & - & $0.104(1.650,10.9 \%)$ & - & 0.078 & 2.723 & $10.9 \%$ \\
\hline 3 & BFF2 & - & $0.122(1.862 ; 7.2 \%)$ & 一 & 0.101 & 3.470 & $7.2 \%$ \\
\hline $3 \mathrm{~A}$ & BFF2M3 & - & $0.111(1.657 ; 10.7 \%)$ & - & 0.077 & 2.745 & $10.7 \%$ \\
\hline 4 & BCHF & - & $0.051(1.019 ; 32.2 \%)$ & - & 0.055 & 1.039 & $32.2 \%$ \\
\hline $4 \mathrm{~A}$ & BCHFM3 & - & $0.097(1.866 ; 7.8 \%)$ & - & 0.147 & 3.445 & $7.8 \%$ \\
\hline 5 & $\mathrm{BE}$ & BFF1 & $0.031(0.149 ; 88.3 \%)$ & $0.088(0.619 ; 54.1 \%)$ & 0.030 & 1.472 & $24.6 \%$ \\
\hline $5 \mathrm{~A}$ & BEM3 & BFF1M3 & $0.081(0.355 ; 72.5 \%)$ & $0.054(0.355 ; 72.5 \%)$ & 0.021 & 1.348 & $27.5 \%$ \\
\hline 6 & $\mathrm{BE}$ & $\mathrm{BFF} 2$ & $0.059(4.62 ; 0.01 \%)$ & $0.082(0.533 ; 59.8 \%)$ & 0.038 & 1.585 & $22.2 \%$ \\
\hline $6 \mathrm{~A}$ & BEM3 & BFF2M3 & $0.098(0.434 ; 66.7 \%)$ & $0.044(0.267 ; 79.1 \%)$ & 0.020 & 1.319 & $28.3 \%$ \\
\hline 7 & $\mathrm{BE}$ & BCHF & $0.126(0.830 ; 42 \%)$ & $0.022(0.342 ; 73.8 \%)$ & 0.000 & 0.640 & $54.2 \%$ \\
\hline $7 \mathrm{~A}$ & BEM3 & BCHFM3 & $-0.011(-0.067 ; 94.8 \%)$ & $0.105(1.442 ; 16.7 \%)$ & 0.035 & 1.346 & $28.7 \%$ \\
\hline 8 & BFF1 & $\mathrm{BCHF}$ & $0.040(0.315 ; 75.7 \%)$ & $0.042(0.685 ; 50.3 \%)$ & 0.000 & 0.443 & $65.1 \%$ \\
\hline $8 \mathbf{A}$ & BFF1M3 & BCHFM3 & $-0.049(-0.363 ; 72.1 \%)$ & $0.105(1.794 ; 9.0 \%)$ & 0.060 & 1.640 & $22.1 \%$ \\
\hline 9 & $\mathrm{BFF} 2$ & BCHF & $0.039(0.313 ; 75.9 \%)$ & $0.042(0.680 ; 50.7 \%)$ & 0.000 & 0.442 & $65.1 \%$ \\
\hline $9 A$ & $\mathrm{BFF} 2 \mathrm{M} 3$ & BCHFM3 & $-0.041(-0.301 ; 76.6 \%)$ & 0.104 (1.768; 9.4\%) & 0.058 & 1.617 & $22.6 \%$ \\
\hline
\end{tabular}

Table 7 Regressions of market beta on accounting betas: Bayesian adjusted betas

\begin{tabular}{|c|c|c|c|c|c|c|c|}
\hline \multirow[b]{2}{*}{ Model } & \multicolumn{2}{|c|}{ Independent variables } & \multicolumn{2}{|c|}{ Cocfficients (l-statistics; P-value) } & \multirow[b]{2}{*}{$\mathbf{R}^{2}$} & \multirow{2}{*}{$\begin{array}{l}\text { Model } \\
\text { F-value }\end{array}$} & \multirow{2}{*}{$\begin{array}{l}\text { Model } \\
\text { P-value }\end{array}$} \\
\hline & $\mathbf{X} 1$ & $\mathrm{X} 2$ & $\mathrm{X} 1$ & $\mathbf{x} 2$ & & & \\
\hline 1 & $\mathrm{BE}$ & - & $0.135(1.219 ; 23.2 \%)$ & - & 0.044 & 1.486 & $23.2 \%$ \\
\hline IA & BEM3 & - & $0.132(1.439 ; 15.9 \%)$ & - & 0.056 & 2.070 & $15.9 \%$ \\
\hline 2 & $\mathrm{BFF1}$ & - & $0.181(1.631: 11.3 \%)$ & - & 0.079 & 2.660 & $11.3 \%$ \\
\hline $2 A$ & BFF1M3 & - & $0.139(1.346 ; 18.8 \%)$ & - & 0.054 & 1.810 & $18.8 \%$ \\
\hline 3 & BFF2 & - & $0.164(1.556 ; 13.0 \%)$ & - & 0.072 & 2.420 & $13.0 \%$ \\
\hline $3 \mathbf{A}$ & BFF2M3 & - & $0.120(1.234 ; 22.6 \%)$ & - & 0.044 & 1.521 & $22.6 \%$ \\
\hline 4 & BCHF & - & $0.253(1.591 ; 12.9 \%)$ & - & 0.123 & 2.530 & $12.9 \%$ \\
\hline $4 A$ & BCHFM3 & - & 0.257 (1.905; 7.1\%) & - & 0.154 & 3.629 & $7.1 \%$ \\
\hline 5 & BE & BFF1 & $-0.041(-0.177 ; 86.0 \%)$ & $0.218(0.933 ; 35.9 \%)$ & 0.018 & 1.280 & $29.4 \%$ \\
\hline $5 \mathrm{~A}$ & BEM3 & BFF1M3 & $0.091(0.403 ; 69.0 \%)$ & $0.050(0.208 ; 83.6 \%)$ & 0.000 & 0.928 & $40.7 \%$ \\
\hline 6 & BE & $\mathrm{BFF} 2$ & $0.082(0.405 ; 68.8 \%)$ & $0.097(0.495 ; 62.4 \%)$ & 0.010 & 1.156 & $32.9 \%$ \\
\hline $6 \mathrm{~A}$ & BEM3 & BFF2M3 & $0.139(0.688 ; 49.7 \%)$ & $-0.007(-0.033 ; 97.4 \%)$ & 0.000 & 0.905 & $41.5 \%$ \\
\hline 7 & $\mathrm{BE}$ & $\mathrm{BCHF}$ & $0.092(0.449 ; 66.0 \%)$ & $0.188(0.740 ; 47.1 \%)$ & 0.000 & 0.984 & $39.8 \%$ \\
\hline $7 \mathrm{~A}$ & BEM3 & BCHFM3 & $-0.018(-0.101 ; 92.1 \%)$ & $0.274(1.450 ; 16.5 \%)$ & 0.042 & 1.413 & $27.1 \%$ \\
\hline 8 & BFF1 & $\mathrm{BCHF}$ & $-0.028(-0.158 ; 87.7 \%)$ & $0.284(1.247 ; 23.2 \%)$ & 0.007 & 1.065 & $36.9 \%$ \\
\hline $8 \mathrm{~A}$ & BFF1M3 & BCHFM3 & $-0.079(-0.500 ; 62.3 \%)$ & $0.294(1.865 ; 7.9 \%)$ & 0.074 & 1.794 & $19.5 \%$ \\
\hline 9 & BFF2 & $\mathrm{BCHF}$ & $-0.029(-0.182 ; 85.8 \%)$ & $0.285(1.286 ; 21.8 \%)$ & 0.008 & 1.070 & $36.8 \%$ \\
\hline $9 \mathrm{~A}$ & BFF2M3 & ВСНFM3 & $-0.068(-0.445 ; 66.2 \%)$ & $0.290(1.837 ; 8.3 \%)$ & 0.071 & 1.764 & $20.0 \%$ \\
\hline
\end{tabular}

African context. As such it possibly points to the relevance of cash flow disclosures as required in terms of $\mathrm{ACl} 18$ (1988).

It must be pointed out that the research does contain a survival bias which is inherent in the accounting beta research design. The problem of the small sample size may possibly be overcome if one were to ignore the requirement of a fixed year-end. This would, however, force one to accumulate February year-end data with December year-end data in order to determine the accounting variables' market index. Although this is not ideal, the increase in the sample size may have greater statistical benefits.

\section{References}

Baran, A., Lakonishok, J. \& Ofer, A.R. 1980. 'The information content of general price level adjusted earnings: Some empirical evidence', The Accounting Review, Vol. 55, No. 1: 22-35.

Beaver, W., Kettler, P. \& Scholes, M. 1970. 'The association between market determined and accounting determined measures of cash flow', The Accounting Review, Vol. 45, No. 2: 654-682. 
Beaver, W. \& Manegold, J. 1975. 'The association between market-determined and accounting-determined measures of systematic risk: Some further evidence', Journal of Financial and Quantitative Analysis, Vol. 10. No. 2: 231-284.

Bhattacharya, K. 1986. 'Cash flow and a company's health', Accountancy, Vol. 97, No. 1112: 130-131.

Bowen, R.M., Burgstahler, D. \& Daley, L.A. 1986. 'Evidence on the relationships between eamings and various measures of cash flow', The Accounting Review, Vol. 61, No. 4: 713-725.

Bowman, R.G. 1979. 'The theoretical relationship between systematic risk and financial (accounting) variables', The Journal of Finance, Vol. 34, No. 3: 617-630.

Bradfield, D.J. 1989. 'A review of capital market theory from a South African perspective', De Ratione, Vol. 3, No. 1: 2-7.

Chastain, C.E. \& Cianciolo, S.T.A. 1986. 'Strategies in cash flow management', Business Horisons, Vol. 29, No. 3: 65-73.

Christie, A.A. 1987. 'On cross-sectional analysis in accounting research', Journal of Accounting and Economics, Vol. 9, No. 6: $231-258$.

Christie, A.A., Kennelly, M.D., King, J.W. \& Schaefer, T.F. 1984. 'Testing for incremental information content in the presence of collinearity', Journal of Accounting and Economics, Vol. 6, No. 6: 205-217.

Dhaliwal, D.S. 1986. 'Measurement of financial leverage in the presence of unfunded pension obligations', The Accounting Review, Vol. 61, No. 4: 651-661.

De Villiers, J.U. 1988. 'Providing for share splits, share consolidations, stock dividends and rights issues: A practical note'. The Investment Analyst, No. 87: 26-28.

Drina, R.E. \& Largay, J.A. 1985. ' Pitfalls in calculating cash flows from operations', The Accounting Review, Vol. 60, No. 2: $314-326$

Gevers, W.R. 1989. Equivalent dividends: An extension. Unpublished Working Paper No. WG/02. Stellenbosch: University of Stellenbosch Business School, 11p.

Gombola, M.J., \& Ketz, J.E. 1983. 'A note on cash flow and classification pattems of financial ratios'. The Accounting Review, Vol. 58, No. 1: 105-114.

Ijiri, Y. 1980. 'Recovery rate and cash flow accounting', Financial Executive, Vol. 48, No. 3: 54-60.

Ismail, B.E. \& Kim, M.K. 1989. 'Notes on the association of cash flow variables with market risk: Further evidence', The Accounting Review, Vol. 64, No. 1: 125-136.

Kochanek, R. \& Norgaard, C.T. 1987. 'Funds statement: Why the focus has changed from working capital to cash flow', Financial Execulive, Vol. 55, No. 1: 27-31.

Retief, J.le R., Hamman, W.D. \& Affleck-Graves, J.F. 1984. 'The measurement of risk', S.A.J. Bus. Manage., Vol. 15, No. 4: 205-211.

South African Institute of Chartered Accountants, Accounting Practises Board. 1988. Cash flow information (AC 118), 14p.

Vasicek, O.A. 1973. 'A note on using cross-sectional information in Bayesian estimation of security betas', The Journal of Finance, Vol. 28, No. 5: 1233-1239.

Wilson, G.P. 1986. 'The relative information content of accruals and cash flows: Combined evidence at the earnings announcement and annual report release date', Journal of Accounting Research, Vol. 24 (Supplement): 165-200.
Appendlx A Sample list of companies

Abercom Group Lid.

African \& Overseas Enterprises Lid.

Anchusa Holdings Lid.

Anglovaal Industries Ltd.

Beares Lud.

Berzack Brothers (Holdings) Lid.

Berzack-Illman Investment Corporation Ltd.

Brian Porter Holdings Lid.

Canadian Overseas Packaging Industries Lld.

Central African Cables Lid.

Claude Neon Lights (S.A.) Ltd.

Consol Lid.

Cullinan Holdings Lid.

Currie Motors (1946) Lid.

Die Afrikaanse Pers (1962) Bpk.

Edward L. Bateman Ltd.

Everite Lid.

Garlick Ltd.

General Optical Company Lid.

Globe Engineering Works Ltd.

Grinaker Holdings Ltd.

Gubb \& Inggs Lid.

Gypsum Industries Lid.

Industrial and Commercial Holdings Group Ltd.

Irvin \& Johnson Ltd.

Mathieson and Ashley Holdings Ltd.

McCarthy Group Ltd.

Metje and Ziegler Lid.

Micor Holdings Ltd.

Mobile Industries Ltd.

Montays Ltd.

Murray and Roberts Holdings Ltd.

National Bolts Lid.

Nictus Finansiële Instellings Bpk.

Picardi Investments Ltd.

Press Supplies Holdings Lid.

Putco Lid.

Rentmeesterbeleggings Ltd.

Rex Trueform Clothing Co. Ltd.

Seardel Investment Corporation Ltd.

Silverton Tannery Ltd.

South Allantic Corporation Ltd.

Steelmetals Ltd.

Suncrush Ltd.

T.W. Beckett and Company Ltd.

The Union Cold Storage of South Africa Lid.

Tollgate Holdings Ltd.

Towles, Edgar Jacobs Ltd.

Tradegro Lid.

Trencor Ltd.

Union Wine Ltd.

Vaderland Beleggings Bpk.

Welfit Oddy Holdings Ltd. 